This paper has been published in its final form as Mark Finnane, 'Terrorism and government: between history and criminology' ANZ Journal of Criminology, Vol. 46, No. 2 (August 2013), 159-177 DOI: 10.1177/0004865813483296

\title{
Terrorism and government: between history and criminology
}

\section{Mark Finnane*}

\begin{abstract}
:
Incontestably the decade since $9 / 11$ has been the pre-eminent age of terrorism. Or has it? In this lecture we consider terrorism as an object of government and of academic research. In arguing that law and criminology have been the pre-eminent disciplines attending to governmental responses to terrorism we note that their interventions have been significant in both their critical stance and in their impact in shaping discourse about the tactics and limits of counter-terrorism, particularly legislation and its uses. But what understanding of the broader role of government in responding to terrorism emerges from such a literature? And what histories are available to inform such an understanding? Existing historical accounts of Australian security and intelligence as a response to political violence and terrorism are for the most part dominated by Cold War politics and ideology, especially through their preoccupation with the politics of intelligence organisations. Increasing availability of security archives, together with a more international view of the context of Australian counter-terrorism histories, provide a sounder base for assessing the emergence of terrorism as an object of government attention since the 1970s.
\end{abstract}

Keywords: Terrorism, counter-terrorism, government, history, Australia, security *ARC Australian Professorial Fellow, ARC Centre of Excellence in Policing and Security, Mt Gravatt campus, Mt Gravatt, Qld 4122, Australia; email: m.finnane@griffith.edu.au. Acknowledgments

This paper was originally delivered as the $34^{\text {th }}$ John Barry Memorial Lecture at the University of Melbourne, October 2013. As ever, thanks are due to John Myrtle for his research assistance. This research has been supported by the Australian Research Council (DP0771492). 
It is forty years since Geoffrey Sawer, co-author of JV Barry's first book, presented the first Sir John Barry Memorial Lecture. He was succeeded in the following year by the judge's close friend, Norval Morris, Professor of Law at the University of Chicago, and the first academic appointment to the University of Melbourne's Department of Criminology. Many distinguished researchers, lawyers, judges and public servants have followed them. It is therefore a great honour to have this opportunity to join the list.

Having had the good fortune of accessing his papers and interviewing many of his family, friends and associates for the biography of Sir John Barry, I am all the more conscious of the challenge of meeting the high standard that the judge would have set for any who embark on the task of interpreting both past and present in the vexed fields of criminal justice, policing and security. If I meet that challenge in any way it is in part due to the continuing research support of my colleague, collaborator, co-author and friend John Myrtle, for many years the Principal Librarian of the JV Barry Memorial Library at the Australian Institute of Criminology.

In the breadth of its engagement across disciplines, Sir John Barry's intellectual and professional work is also a challenge to address without fear or favour the kind of topic we consider here. We do well to remember that this pioneer of Australian civil liberties was a person who did not shrink from the task of both judging and administering when the time called for it. We don't know exactly what he would have made of the history of contemporary governments responding to terrorism. But in spite of Barry's pre-war resistance to a conservative government amending the Crimes Act in ways that affronted his sense of liberty (Finnane, 2007: 80-3; Waghorne and Macintyre, 2011: 13-14), he was ready to serve on the wartime government's committee advising on the scope and mechanisms of wartime internment of aliens. In that task he brought to the table an acute sense of what was just, as well as desirable, in managing that era's domestic security anxieties.

One story from that time might signal the kind of intervention that Barry might have made in debates of the last decade over the law's role in countering terrorism. The Australian approach to internment in wartime was straightforward - lock up enemy aliens first and then release progressively those who were not a threat (Bevege, 1993; Neumann, 2006; Saunders, 1992). As is well known, many of those classed as 'enemy aliens' were in fact refugees from Nazi Germany. In 1943 the Commonwealth Director-General of Security queried the need to reassess the status of all enemy aliens to establish who were properly refugees. He regarded the benefits of such a reassessment as not likely to exceed the 'mental satisfaction' of the 
refugees concerned. To this Barry and other members of the Aliens Classification and Advisory Committee strongly objected. The reputation of the Commonwealth, relative to the standards applying in other Allied countries, was dependent on this issue. After all the Allied powers were fighting for 'the preservation of certain real and essential human values, and ... amongst these is justice to the individual'.

We feel, therefore, that there is involved far more than the 'mental satisfaction to the individual of knowing he was a refugee'. We insist that there is also involved one of the essential features of the ideology we fight to preserve, namely, the recognition of the right of every man to an opportunity to be judged justly and in accordance with the fact (Finnane, 2007: 112-3).

\section{The subject of terrorism}

Whose business is the subject of terrorism? The enormous volume of writing on the subject in the last decade, or even the last four decades, suggests that it's first of all a public business. Books on terrorism for a general audience abound, though perhaps not yet enough to become a staple on the model of the True Crime genre. The use of the word 'terrorism' became a major topic in the Australian parliament after 2001, an acceleration of a trend that began in the 1970s. A longer perspective on the use of the word in the media suggests that terrorism has gone through some peaks and troughs, with notable incursions on the public consciousness in the 1880s (associated with the Irish troubles as well as the impact of European anarchism) and the 1930s (connected especially with the emerging conflict over the status of Palestine, between Britain, the Palestinians and Zionists).

When it comes to the academy - by which I refer generally to scholarship conducted in universities - terrorism is pretty much the business of law and criminology. That at least is the case in Australia, judging by review of the literature over the last 40 years. In spite of the great importance of the topic in the considerations of government during this time (as we will see) the disciplines of government, politics or political science have displayed only limited interest, and generally in the area of international relations more than political studies concerned with the processes of government, public policy and domestic political relations(Jones, 2010a, 2010b; McDonald, 2007; O’Neil, 2005, 2007). History too has been little concerned to attend to the matter - the depth of contributions on the conflict and violence of colonial settlement contrasts with the thinness of the literature dealing with the twentieth century history of political violence as it affected Australia (Brawley, 2009; 
Koschade, 2007; Rawson, 1968; Turner, 1969). A small but distinctive literature deals with the history of political surveillance and intelligence organisations, a topic to which we turn later.

This narrowness of the response means that if we want to know about terrorism and government, the subject of this talk, we are largely at the mercy of two disciplines, law and criminology, that have written a great deal about it in recent years, building on slight foundations from an earlier time (Milte, 1975a, 1975b; Wardlaw, 1982, 1986). What have the disciplines of law and criminology told us about the contemporary phenomenon of terrorism as an object of government attention in Australia? From law and criminology the overwhelming weight of opinion in academic commentary has been hyper-critical. What has settled as an orthodox treatment may be summarised in this way.

While there may have been terrorism before 9/11, and a government response to it, the events of that time and the subsequent more local impact of the Bali bombing have inspired an extraordinary raft of special legislation, accompanied by an escalation of government resources devoted to policing and surveillance. The legislative activism has resulted in laws that risk harming the human rights of suspects and innocent people alike (Bronitt and Stellios, 2006; Bronitt, 2003, 2008; Gani and Mathew, 2008; Lynch et al., 2007; Lynch and Williams, 2006; McGarrity et al., 2010). The policing and prosecution of actions that harm has been expanded to include actions or even thoughts that might result in a future terrorist action, in a strategic manoeuvre that has been characterised as 'pre-emption' (McCulloch and Pickering, 2009). Vulnerable communities have been disadvantaged and harmed by the imputation of risk of violence attached to their religious beliefs through the criminalisation of motives, political, religious or ideological (Poynting, 2004). Immigration has been said to be securitised, or worse, has itself been a site of state crimes (Grewcock, 2009; Pickering, 2005; Weber and Bowling, 2004). Two larger risks are said to be associated with the decade of anti-terrorist initiatives since 9/11. One is the militarisation of security, said to be evident in the policing of mass protest around global events (Head, 2009; McCulloch, 2001). The other is the leakage or creep of anti-terrorist law into other areas of social control, harming the human rights of minorities and extending the use of pre-emption (Williams, 2011; Zedner, 2005, 2009).

A different approach, more associated with criminology than law, has sought to understand the challenges and approaches of responding to terrorism through the lens of lessons from crime control. Some have debated whether deterrence works with individuals or 
communities inspired by religious or ideological zeal, millenarian and utopian (Braithwaite, 2005; Findlay, 2005; Goldsmith, 2005). Others have sought to draw comparisons with the governmental preferences of contemporary crime control, seeing the emergence of a 'governing through terrorism' complex, or alternatively and more broadly the emergence of 'preventive partnerships' in a refinement of the management of risk (Bull and Craig, 2006; O'Malley, 2011; Palmer and Whelan, 2006). As promising as these broader implications might be for contemplating the governmental significance of counter-terrorism, they have not inspired a raft of studies in political science or public policy. Undertaking a study of critical infrastructure governance, a researcher coming from a public service career in a State transport department was surprised to find not a single Australian study preceding her own (O’Donnell, 2011).

It will be evident that I am leaning towards a conclusion that the scholarship on post 9/11 counter-terrorism has been focussed on only some parts of this complex, ignoring others. While this lecture will seek to fill in some other gaps, I think it notable that the critical reception of counter-terrorism law and policing has in turn been a potent political force that we should not underestimate. Australia might have been exceptionally robust in its lawmaking, but one is tempted to conclude that law-making has provoked more debate and review than it has prosecutions. The political and administrative costs of legalist adventurism have been high, if measured by the establishment of numerous reviews, the conduct of parliamentary committee hearings, and the creation of new oversight mechanisms to supplement those already in place. To the extent that they have participated in the public debate and pressure that have produced those outcomes we might imagine that the scholarship of law and criminology has demonstrated its impact in good measure over the last decade of contention over counter-terrorism.

What guidance does such a literature provide us however in understanding the scope and resources of government devoted to security? I want to suggest here that the scholarship has given us only a partial account of the wide-ranging involvement of government in responding to terrorism since the 1970s. In its focus on the law of counter-terrorism and on the rights of those investigated for alleged terrorist activities the literature of law and criminology draws its own boundaries around the subject, limiting attention to a wider complex of state action, institutions and co-ordination. In its anxiety over the human rights implications of even unused law, the literature gives us a skewed picture of the development and mechanisms of the modern security state. Sometimes, as I will suggest, this focus will 
distort its account of what is going on when governments and agencies do their security business.

\section{The pretext of terrorism?}

In the account given by its principal historian, Australia's counter-terrorist state was the product of a determined grasp of executive control by political forces limiting our democracy and individual rights. In her well-researched but partial account of the emergence of terrorism as a labelling practice that signalled the triumphant resurrection of ASIO (the Australian Security Intelligence Organisation) out of a decade of ignominy, Jenny Hocking argued not once but twice, before and after 9/11 and Bali, that terrorism was a pretext for ASIO's institutional recovery in the 1980s (Hocking, 1993, 2004). This she suggested was made possible by the compliant and befuddled review of domestic security of the Hope Royal Commission (1974-78) and the Protective Security Review (also chaired by Hope) of 1979.

Two events are critical to Hocking as to others: the Murphy 'raid' on ASIO in March 1973 and the Hilton Bombing in February 1978. The former in her view was a disaster for Murphy (see also (Hocking, 1997)) but is a moment that concentrates the conflicts over political accountability of the intelligence services in a way that makes intelligible the later establishment of the Royal Commission (Hocking, 2004: 43). With the Hilton bombing, '[t]he Australian security context was reversed overnight'(Hocking, 1993: 112) - but this is the beginning of a story of decline, a retreat into government policies obsequious to security interests, especially to those of ASIO. Supplementing ASIO's grab for relevance was the Army's post-Vietnam search for a domestic role. Hocking's account of 'the pretext' of terrorism has been influential and informs other accounts of Australia's security policies and institutions ((Burke, 2008; Head, 2009; Jones, 2010b; Roach, 2011; Williams, 2011). In such accounts, Australia's relatively untroubled domestic political history is contrasted with the paranoid world of a state and its agencies defending itself against imagined enemies.

There was much about ASIO's behaviour and the politics of its masters from 1949 to 1972 to justify the jaundiced view of its activities that such histories recount. Its lack of formal political accountability, its secrecy, its inscription in the domestic politics of the Cold War and the emerging era of political dissent from the mid-1960s were the object of sustained political and intellectual criticism through these decades and after ( in addition to Hocking see (Cain, 1994, 1994, 2008; Hall, 1978; McKnight, 1994, 2008a)). The history of ASIO indeed was written under the sign of the Cold War and its cantankerous politics. The 
passing of the Cold War, together with the opening up of its archives in many places, has only slowly shaped a more sober and complex view of its institutional history (Ball and Horner, 1998; Manne, 1987; McKnight, 2008b). The gradual loosening of the legacy of the Cold War and the politics of secrecy in national security has by now encouraged ASIO to contract its own official history (under the direction of Professor David Horner of ANU, first volume to be published in 2013). Yet is it symptomatic of the sense of a still beleaguered organisation that the Australian domestic security agency can have an official history that extends only to the year 1978, in contrast to the official history of Britain's MI5, which was authorized to extend its remit to the present day (Andrew, 2009)?

Whatever ASIO's sins of omission and commission during the Cold War, I propose below that the emergence of terrorism as an object of government attention in the 1970s was not the product of ASIO's intervention, or invention. Nor was it a pretext for determining ASIO's survival, a new justification for resources and relevance in the 1980s. I want to suggest here that terrorism instead emerged as a more comprehensive concern of government in the 1970s through a process that was both more piecemeal and more international in its course and orientation than recounted by Hocking. I do so by highlighting the impact of an event, charting the course of a committee and its agenda, and stressing continuity as much as rupture across changes of government and administration and political climate. Through such an account I will argue that existing histories of terrorism and government in Australia have been too narrow in their institutional focus and too exclusive in their jurisdictional and geo-political attention.

\section{After Munich}

Forty years on from the election of Gough Whitlam, it is easy to forget that there was another government in power for most of 1972. It was the McMahon Liberal-Country coalition government which in fact was first prompted to act on terrorism. In October 1972 the government established a Committee on Terrorism and Violence in Australia. This is a story easily forgotten - the Cabinet meeting establishing the committee was also the one that determined the 1972 election date, one the government was likely to lose. Over a number of weeks prior to the election however the committee pursued an agenda that demands attention. The context of the committee's establishment that should be recalled.

On 5 September 1972 eight Black September commandos of the Palestine Liberation Organisation took hostage at the Munich Olympic village 11 Israeli athletes, trainers and 
officials. During the initial hostage-taking two of the Israelis were shot and killed. In protracted negotiations over the course of the day the German governments (ie Federal as well as Bavarian) eventually approved a proposal for the hostages and their captors to be taken to Fuerstenfeldbruck airfield near Munich to be flown out of the country. At the airfield, a catastrophic series of events resulted in all the hostages and five of the captors being killed. The surviving Palestinians were later released by the German government during succeeding terrorist actions. In retaliation the Israeli government struck at Palestinian locations in Lebanon and Syria; later the Meir government authorised the secret assassination of all those associated with the organisation of the operation at Munich. The inept handling of the crisis by the Federal German and Bavarian governments exposed to world view the vulnerability of states and peoples to well organised and determined terrorist attacks (Reeve, 2011).

This event touched off a complicated international reaction, even though the specific actions were widely condemned. At the United Nations the Secretary-General initiated a resolution calling for action on terrorism. The difficulty of making progress at the United Nations was demonstrated in the contrasting approaches taken by alternative draft resolutions put on the table of the Assembly in late November. One, with the support of a number of countries headed alphabetically by Afghanistan, sought to reaffirm the right of selfdetermination of all peoples in the face of colonialism and racism; the other, with the support of a different group of countries headed alphabetically by Australia, insisted on action against terrorism even if its underlying causes also needed attention ${ }^{1}$.

A stronger imperative driving Australian government action was the initiative of the United States government in marshalling its own resources to combat terrorism. US foreign policy interests were mindful not only of Israel but of the Middle-East and Arab states generally (Briggs, 2011). The politics of oil was not far from American minds. Oil was not an Australian export commodity but an internal Foreign Affairs Department minute on Australian response options was no less mindful of some basic interests:

Australia enjoys friendly relations with both the Arab states and Israel. It is not in our broad national interests to be appearing to favour one side or the other in their disputes. Our economic relations with the Arab countries are substantial and have shown potential for growth. The value of our wheat exports to Egypt is \$A100,000,000. We have large Jewish and Lebanese communities in Australia; our support for Israel as a state and for its security (along with the security of Arab states) 
is long \& firmly established. There would therefore be positive disadvantages for Australia's interests in a one-sided debate on recent events.

There follows a proposal for political management of a volatile situation that is of particular interest in terms of the construction of terrorism as an object of policy.

If there is a debate, it might be more profitable to try to steer it away from exclusive concentration on Arab/Israel and Middle Eastern problems and in the direction of the problems of terrorism generally. ${ }^{2}$

In this context the prospects of a distraction from the difficulties of dealing with Middle Eastern politics in Australia were relieved by the bombing a fortnight later of two Yugoslav travel agencies in Sydney. Presumed immediately to be the work of Croatian extremists this event aggravated the already vocal criticism of the Australian government in its attitude to Croatian nationalist militants who had been implicated in a large number of violent attacks on Yugoslav government interests over the previous decade (Aarons, 2001; McKnight, 1994). The government was now driven by both international and domestic politics to take some early steps on the path of anti-terrorism. The Prime Minister William McMahon favoured a Royal Commission but failed to carry Cabinet with him. Instead, on the day his government decided to go to the polls, McMahon's Cabinet also approved the establishment of an Interdepartmental Committee on Terrorism and Political Violence in Australia ${ }^{3}$.

The peculiar circumstances in which this Committee deliberated on Australian measures to combat terrorism have perhaps understandably led to it being forgotten altogether. Less than two months later the Liberal-Country Party coalition surrendered office to Gough Whitlam's Labor Party, an event that explains why this committee appears only to have produced a draft report. I suggest however that this committee left two legacies. First, it established a machinery of inter-departmental consultation on security that endured through two changes of government in the years between the Munich massacre and the 1978 Hilton bombing, and even beyond. The machinery was driven by the Attorney-General's Department, with Prime Minister and Cabinet, Foreign Affairs, and Immigration, as well as co-opted departments including Customs and Excise, Civil Aviation, Interior and the Commonwealth Police Force. ASIO was initially of little importance, represented at only the second of the three meetings. Second the committee became a forum in which the Cold War preoccupations with internal subversion began to be challenged by a perception that there 
were more dangerous and less visible threats to public safety and security. This transition is very evident in the proceedings of the committee, as the initial discussions of the low-level violence associated with political protest and industrial militancy was displaced by higher level concerns with aviation security and the entry into Australia of potential terrorists (Finnane, 2013).

\section{Black September}

The work of administration was continuous in numerous ways as the Labor government took over from late 1972. Many permanent secretaries retained their positions at the head of major departments, notably Sir John Bunting at Prime Minister and Cabinet and Clarence Harders at Attorney-General's. Any sense of business as usual was however early disrupted by the new government's energy, first during the period of the duumvirate (in which Whitlam and his Deputy Lance Barnard shared all ministerial positions), and then in 1973 in the rush to prosecute an ambitious programme of social and economic reform. The historical memory of the first half of 1973 is dominated by the extraordinary and politically rash visit (the ASIO 'raid') by the Attorney-General Lionel Murphy, to ASIO headquarters in Melbourne early on 16 March. This event was prompted by Murphy's suspicion (fuelled by advice from a close adviser, Kerry Milte, a former Commonwealth police officer) that the organisation was not disclosing all that it knew about Croatian extremism in Australia (Hocking, 1997: 145-6).

Yet other work bearing on the subject of terrorism was also taking place. In particular the aviation security agenda retained the priority that it had assumed in 1972. One of Murphy's early initiatives in the Cabinet room was legislation to enable Australia to ratify the 1971 Montreal Convention Relating to Protection of Aircraft - Cabinet approved the submission on $6 \mathrm{March}^{4}$. Such incremental business of government was quickly overshadowed by problems with ASIO and the political furore over Croatian terrorism; this was an unproductive debate, misleading in its attempted indictment of the previous government which had been finally led to its own belated initiative in counter-terrorism, as we have seen. The Labor government's relations with ASIO had to be re-built very quickly the Director-General had to be reassured by Whitlam of the security of his own position and the importance of the organisation's work ${ }^{5}$.

If the political debate was dominated for much of 1973 by what had happened in the past, there were other developments in intelligence and policing that also demand attention. 
The approaching anniversary of the Munich Olympic massacre was a time of anxiety prompted by intelligence that the Black September militants would initiate new terrorist actions. On 30 August 1973 the next step was taken in establishing what would become a long-term mechanism for anti-terrorist planning and capability. Intelligence received by ASIO indicated that the Black September movement might become active in Australia, with specific information that the terrorists would come from Syria. A meeting convened at the Attorney-General's Department, chaired by Frank Mahony (who had also chaired the 1972 Committee), reviewed intelligence and security readiness to respond to such an event. The meeting was attended by officials from seven Commonwealth departments as well as ASIO, the Joint Intelligence Organisation and five police forces. Information about the Black September militants was presented not by ASIO or police, but by Foreign Affairs. The meeting canvassed potential targets, likely to involve Jewish or Israeli personnel or property. Information had also been received from Thai International Airlines that an attack might originate from Japanese terrorists. This was of immediate concern since the Crown Prince of Thailand was about to arrive in Sydney. Commonwealth police advised that the tactics that might be used included hijacking, kidnapping, murder, property damage and letter bombs, all favoured methods of 1970 s terrorism.

In planning for response, a number of approaches were discussed - profiling of potential terrorists, increased security by police, customs and immigration officials at airports and wharves, increased 'percentage checks' on passengers, and a range of other security precautions including checks on firearms' sources. The last was not a hypothetical concern a recent theft of weapons at Bandiana army base near Wodonga had resulted in the loss of 12 sub-machine guns, 12 self-loading rifles and 8 Armalite rifles and ammunition .

The record of decisions coming out of the meeting ran to 25 items - among the most important was the designation of the Commissioner of the Commonwealth Police Force as 'responsible for the co-ordination of all security measures until the end of September'. A wide range of policing precautions was to be put in place, or enhanced above existing levels. So too were immigration control procedures, and civil aviation and airport security measures. Hi-jacking procedures were already well developed by the Department of Civil Aviation: a National Co-ordinating Security Committee oversaw the operation of the Anti-Hijacking Committees which were in place at each airport. The press would be advised of higher security precautions 'because it is the month of September'. State governments and their police forces would be advised of the measures in place. The four departments nominated as 
points of contact included Prime Minister and Cabinet, Foreign Affairs, Attorney-General's and Civil Aviation. ${ }^{6}$ Counter-terrorism was already a broad government mandate, coordinated at Commonwealth level, encompassing many agencies at both Commonwealth and State level.

Implicit in the meeting more than consciously addressed was a scale of security precautions. September was to be a month of higher security preparedness because of the specific association with the threat of Black September. The need to review what would later become known as alertness levels emerged in subsequent meetings of this ad hoc committee, not yet formalised in its agenda or accountabilities. On 5 October another broadly representative conference was convened by Attorney-General's, this time without the State police present, for reasons that will be discussed below. New intelligence from ASIO was that four men 'may have been sent to Australia by the Black September Movement in conjunction with the Popular Front for the Liberation of Palestine some time after 22 September 1973'. This information by itself appears to have driven the recommendation of the Commonwealth Police Commissioner that 'the period of alert should be continued', especially given the pending visit of the Queen. It was also noted however that the Queen's Private Secretary had conveyed the Queen's 'hope that there would not be any over-reaction by Australian authorities in the making of security arrangements" 7

Attention was heightened by the saga of Abdul Hamid Azzam, a Palestinian man who had arrived in Australia on September 7 under an assumed name. When he tried to leave four days later he was arrested and charged with illegal entry, sentenced to 6 months gaol and deported to Cairo on September 26. Azzam admitted to being a Palestine Liberation Organization representative in Somalia ${ }^{8}$.

At Sydney Airport a customs inspection had revealed that his suit case had a false bottom with 'outline markings for a large pistol or small sub-machine gun, three grenades and a 6" x 2" area into which an ammunition box might fit'. He was placed under surveillance for the duration of his stay in Australia. During this time a great deal of communication with overseas Australian posts sought details on his identity and affiliations. From Bahrain it was later learned that he was suspected of involvement in the attack and hostage taking at the Israeli Embassy in Bangkok in December 1972. Other intelligence suggested he had origins in a Palestinian refugee camp in Beirut, a fact which Azzam readily admitted. 
In a Melbourne court, Azzam's defence counsel claimed that he was in Australia to 'check on the activities of PLF supporters and to contact Arab diplomats to discuss whether the Australian Government was likely to accept a PLF information office here'. When the prosecutor attempted to raise counter evidence of Azzam's involvement in 'an international incident' (presumably the Bangkok saga), the magistrate stopped him. Azzam had already been issued with a deportation order, pending the outcome of his trial. A special committee meeting on 17 September, prior to Azzam's trial, considered what might happen if he was acquitted - attending were 10 officers from Attorney General's, Prime Minister and Cabinet, Immigration, Foreign Affairs, ASIO and the Commonwealth Police.

Some indication of the differences between intelligence and policing interests in counter-terrorism emerged. The Commonwealth police were all for deporting Azzam as soon as possible. ASIO favoured keeping him in custody to enable his further interrogation for information relating to terrorism. This difference between policing and intelligence roles has remained a significant and challenging feature of the counter-terrorism domain. Further, in decision-making that anticipates by nearly 30 years the procedures adopted in the Haneef case in 2005, it was decided to cancel Azzam's temporary entry permit anyway. This had the effect of rendering him a prohibited immigrant. If he was acquitted he would immediately be arrested and deported.

As it was, the 6 months gaol sentence on conviction created a different kind of security problem. The Foreign Affairs files disclose a high degree of anxiety about possible attacks on Australian diplomatic posts in the Middle East as news spread of Azzam's arrest and imprisonment. Diplomats were also heavily involved in seeking a country that would accept Azzam. The Lebanese were reluctant, declaring 'one less commando the better'. In the end Somalia was the destination, with Azzam deported under police escort via Kuala Lumpur and Cairo.

In parliament the Opposition's Senator Greenwood raised the allegation that Azzam had been involved in planning the terrorist attack on the Israeli Embassy in Bangkok. The Attorney-General had already been forced to deny strongly a rumour that Israeli security officers had interrogated Azzam - although the files indicate that two other agencies besides ASIO and the police may have interrogated him ${ }^{9}$. In spite of the denials, reports of Israeli involvement were subsequently published in the Middle East and compounded difficulties for Australian diplomats and commercial interests in that region. 


\section{'Terrorist problems arising from the Middle East situation'}

The Azzam experience was a key event whose traces run through later meetings of the Counter Terrorism Committee. ASIO prepared a report on the case, illustrating 'facets of the modus operandi of Arab terrorists' (note the important difference from the recent decades when 'Islamic' rather than 'Arab' terrorists have been the focus of counter-terrorism). This was subsequently circulated to government departments, State police forces and overseas diplomatic posts ${ }^{10}$. The experience appears to have consolidated the determination of the government to put in place more permanent arrangements for counter-terrorism.

Further meetings of the Committee were held on 31 October (by which time the shortlived Yom Kippur War between Israel and the Arab States had been fought and concluded) and 14 November, each time to review the level of precaution. By this time concern was being expressed by aviation authorities about the burden of extra precautions required at airports. But a countervailing agenda had already developed. Both ASIO and Foreign Affairs reported 'definite information that there would be renewed terrorist activity on an international scale'. Prime Minister and Cabinet was now concerned to see a longer-term approach to the "problem of meeting terrorist threats...Effective organisation to meet the problem needed to be developed, and Ministers should be fully briefed on the nature of the problem, its urgency, and the requirements to meet it'.

Alongside this broader government watch, a policing 'Anti-Terrorist Plan' was in preparation, largely focussed on planning for a policing response to a terrorist incident. This appears to have been a direct outcome of the 30 August meeting that had appointed the Commissioner of the Commonwealth Police Force to oversee security measures during September. By mid-September a wide consultation had taken place with all Australian police forces. The draft attended to four items - a plan of operation, the chain of command, means of communication and equipment requirements. Commissioners were recommended to appoint a senior officer to command a group responsible for operations involving terrorist activity. The plan was focussed on two types of incident, a siege involving hostage-taking, and an aircraft hi-jacking. A major terrorist incident in Paris on 5 September (the anniversary of the Munich attack on the Israeli athletes) was an important context for reviewing the need to consider such incidents, and the capacity of Australian resources to respond. ${ }^{11}$ Although the operational planning was informed by policing logics, the recommended Command Group was to include both police and key government departments. The context for this structure related to the political element involved in terrorist incidents. As the plan argued: 
In a siege situation involving terrorists there are special policy considerations giving rise to the necessity to obtain political decisions that are not present in the ordinary siege situations with which police are concerned, such as those relating to mentally deranged persons or violent criminals. ${ }^{12}$

Detailed operational measures and requirements were spelled out. The plan recommended that each State review its Disaster Plans, and alert State Emergency Services to the potential call on their resources. Recommended weaponry was based on the array of existing equipment held by the NSW Police Force. The quantum of weaponry was significant, but a widely acknowledged failure of the German police at Munich the previous year had been the shortage of significant weapons. ${ }^{13}$

An item of particular interest in the draft plan, especially in retrospect, was the discussion of other support to police in an emergency. The matter was raised in the context of considering the needs for supplementing police force personnel, including the use of police reserves. A final note under the heading 'Other Forces' raised another possibility: 'give consideration to requesting assistance of the Defence Forces as a last resort. THIS SHOULD NOT BE SOUGHT UNLESS PRIOR APPROVAL HAS BEEN GIVEN BY THE HIGHEST AUTHORITY [emphasis in original]. ${ }^{14}$ The highlighted caution is noteworthy and had its effect. Subsequently within Attorney-General's Department legal advice on the question of military aid to the civil power was to be prepared, long in advance of its later activation during the so-called siege of Bowral. We will return to this matter. Equally noteworthy in these discussions is the absence of any sense that Australian threats might be of the kind being met in Britain and Northern Ireland, where bombing and assassination more than hostage taking and hijacking were the weapons in use. Rather the concern was over the intrusion into Australian domestic space of attacks associated with problems in the Middle East, especially involving diplomats and others linked with Israel.

In mid-November a further meeting was called, again involving a large number of departments and many police forces, to consider the establishment of a more permanent oversight body on security matters. Its attention was devoted first to advice from ASIO, the Commonwealth Police and the Immigration Department about the status of three Afghans who had been trying to obtain visas to enter Australia: the men claimed to be university lecturers, but in Singapore they had shown an Australian labourer $\$ 8000$ they were holding. The widely shared concern over the status of these prospective visitors led later to the Immigration Minister refusing their visa applications. The larger business of the meeting was 
to approve the proposals first, to introduce a 'two level precautions system' ('alert' and 'special precautions') and second, to establish a 'special interdepartmental committee to replace the present ad hoc ... meetings, to deal with the terrorist threat on a long term basis'. 15

With the approval of Prime Minister Whitlam and Attorney-General Murphy, the Special Interdepartmental Committee on Counter-Terrorism' was then established, holding its first meeting on 26 November 1973. Chaired by an officer from Attorney-General's, the membership was narrower than the ad hoc committees: Prime Minister and Cabinet, and the Commonwealth Police and ASIO were the other permanent members. Other departments and agencies would be invited as needed. The Commonwealth Police was to act as co-ordinator of the Committee and communications arising out of it. ${ }^{16}$ The scope of business was quite specific, relating to 'terrorist problems arising from the Middle East situation'. Other matters would require 'approval or referral by Ministers'.

In addition to vigilance in Immigration Department checking of visas, the permanent committee early identified a survey of oil installations in Bass Strait as a priority, following an approach from the ESSO company's security officer. The major concern in late 1973 however continued to be airport security. Two days before the second meeting in December, a disastrous terrorist attack at Rome airport resulted in more than 30 people being killed at the airport and on a plane where the attackers sought refuge. The problem of transiting passengers was highlighted by this event - lax procedure meant that such passengers could transit through Australian airports without visas and without baggage security checks. The Rome events prompted the Committee to request Foreign Affairs for advice from Australian posts abroad on the 'negotiations and incidents during the recent Rome aircraft attack and hijacking and other recent similar incidents'. ${ }^{17}$

In effecting the focus on international terrorism an early challenge to the Committee's agenda was a legacy of ASIO's traditional focus on internal subversion. A key moment was the intrusion on the Committee's agenda of the alleged threat of Aboriginal violence. At the March 1974 meeting, following a review of responses from various departments to an ASIO intelligence report that 14 terrorists were training in Australia, the Committee considered a second item. The problem had been referred by the Secretary of the Attorney-General's Department, who asked the committee to consider whether it 'could take under its ambit the co-ordination of activities relating to the special problem of developing Aboriginal extremist violence'. Further discussion is not on record but the committee disposed of the matter by 
recommending to the government that another special committee be established to coordinate advice 'upon special problems of domestic violence'. The membership of the Special Interdepartmental Committee on Domestic Violence largely replicated that of the Counter-Terrorism Committee, but with the addition of the Department of Aboriginal Affairs 'as necessary'. ${ }^{18}$ Its agenda included a watch on the activities of Croatian nationalists in Australia.

\section{A governance of terrorism}

Over the succeeding years to 1978, and with only a slight bump at the end of 1975, the Interdepartmental Committee on Counter-Terrorism remained the key mechanism monitoring the risk of terrorism and the preparedness of Australian agencies to respond to terrorist events. Indeed the central objective of counter-terrorist planning in the $1970 \mathrm{~s}-$ to guard against and be ready to respond to a terrorist siege, including hostage-taking and possible hi-jacking of aircraft - remained in place when the 1973 Anti-Terrorist Plan was finally replaced by a new Plan in 1980, following the Hope Protective Security Review (O’Donnell, 2011: Appendix 2 p6) ${ }^{19}$.

A detailed history of the proceedings of the committee would quickly exhaust the space available here. What may be valuably learned however is the range of interventions considered necessary in order to prepare for a possible terrorist event. So here we may briefly summarise the main work of government in forging counter-terrorism at this early date.

Whatever the difficulties of defining what terrorism was or is, and whatever the ambiguities and slippages that inhere in it, the focus of counter terrorism policy was international more than domestic, and principally on the activities of Palestinian terrorism. Threats would come from the entry into Australia of activists seeking to attack Israeli diplomats and associates, including their Australian allies - in this context Bob Hawke, then President of the Australian Council of Trades Unions and an outspoken defender of Israel, was considered a vulnerable figure, the only non-Jewish person singled out for mention in the Committee discussions as they drew on advice from ASIO and the Commonwealth Police.

With almost all (97\%) passenger entry and exit to and from Australia through a small number of international airports a priority for planning was the securing of airport perimeters and of passenger movement through the airports. The key department was Civil Aviation, already involved in response planning through the creation of Anti-Hijacking Committees and local command groups, with police taking a key role. A review of airport perimeters in 
1976 found still that none of the airports had secure fences; an earlier review of radar systems had unearthed the fact that Darwin airport had no radar coverage out of business hours. ${ }^{20}$ The problems were formidable and only slowly addressed. Passenger movement was the business of the Immigration Department. The dependence on manual card systems and lack of computer infrastructure and processing capability meant that there was in 1976 a gap of between 6 and 9 weeks in the processing of incoming and outgoing information. Any emergency scanning of passenger movement had to be done manually by more intense staffing of immigration checkpoints. Screening of passengers and baggage for firearms and other weapons was in its infancy - 'magnetometers' were slowly being adopted but there was nothing comprehensive. Transiting passengers were not separated from incoming passengers before modifications to airport terminals were progressively built during 1975-6. All these deficiencies emerged as Australian officials reviewed local systems in response to information accumulating from the major terrorist attacks on airports and planes from 1972 to $1976 .^{21}$

Australia's long-standing strict regulation of immigration was undoubtedly an enviable resource for any emerging counter-terrorist response to external threats. In spite of some softening of Australian foreign policy on the future of Palestinian demands against Israel, there was no evidence of a softer stance on militants - deportation was a swift resort against suspected Fatah and Black September agents in 1973 (in addition to Azzam an alleged Black September agent was deported in December ${ }^{22}$ ). A suspicion around any Palestinian and other Middle-Eastern political activists continued to inform bureaucratic advice to a cautious government. Within the framework of advising government, Immigration Department played a key role, especially once it was brought back in to the Committee in 1976 after the Fraser government took office.

A final element of continuity of longer-term interest was the insertion of the military into the armoury of government response to terrorism. Whatever the origins of the military interest in Australian counter-terrorism capability (in Hocking's view, a discovery of a new role for the SAS (Hocking, 1993: 191)), the development of the original Anti-Terrorist Plan by police and civil department officers in 1973 was the key element. The 'Operational Plan' put in place on 18 September 1973 involved the establishment of a Command Group to coordinate action in contemplation of a possible siege or highjack. A large number of departments was implicated in preparations, but Defence was not one of them. 
When the matter of military aid came up for more considered attention in early 1976, it was more clearly identified as a problem, one that required legal advice from the AttorneyGeneral's Department. But that followed from the cautionary approach that Defence had already adopted from at least late 1974. The conduct of Anti-Terrorist exercises to be held in 1975 was the context of requests from police for possible assistance from Defence in equipment and resources. Defence appeared interested but wanted advice first of all from Attorney-General's on their position in such an exercise. The Department of Prime Minister and Cabinet was reported to be very interested in the outcome of this advice ${ }^{23}$. When that advice came through a year later it became evident that Defence might need to be involved more continuously in any counter terrorism planning. There is little sense of Defence driving this position - rather the policy was being driven by other parts of government, concerned to know whether the country would have an adequate capacity in the event of a major terrorist incident. In October 1976 Federal Cabinet directed the Minister for Defence to establish training of special forces for counter-terrorism, since 'it would be unrealistic to plan on the basis that police forces alone would be adequate to deal with all possible future acts of terrorism'. Simultaneously the Attorney-General was directed to advise on legislation to 'ensure the prompt and effective call-out of Defence Force personnel, in the event that this was required'. 24

The lesson from this narrative is that the role of Defence in counter-terrorism was responsive, more than driven by an urgent Defence interest in the role, however much it may have been of particular interest to the SAS (Hocking, 2004: 112-4; Horner, 2002: 419-21) . When the Hilton bombing prompted the call-out of troops, it was the nature of the incident as well as its international context that catalysed the action. Instead of a siege or a hijacking, the focus of most counter-terrorist discussion since 1973, the emergency faced by the government was a bombing. This was not an event that looms large in any of the discussions of terrorism in the years from 1972 to 1978, in spite of the concurrent experience of urban bombing campaigns conducted by the IRA in Ireland and Britain during these years. Throughout the consideration of the counter-terrorism committees during these years, the focus was on Middle-Eastern security issues, which implicated a wide range of activists associated with the various Palestine liberation movements and their associates. An important element of the reaction to the Hilton bombing was the novelty of the threat - for governments and security agencies that had worried over the continuing threats from Middle Eastern terrorism, or even the IRA, the impact of a bombing posed unexpected challenges. 


\section{Counter-terrorism and government}

If we compare the response to terrorism in Australia over the last decade with the 1970s, some important differences are evident. I think they can be summed in these terms - a proliferation of laws, a domestic security politics of immigration, and an aggrandised intelligence and policing community. For critics, these developments have been regrettable, even dangerous. New laws are said to infringe human rights and threaten to leach into other areas of law, perverting the protections of existing criminal law. Immigration has become a site for intense scrutiny of political choices, international obligations and legal contestations. To effect these laws and secure these borders, a great increase in intelligence and policing personnel, with accompanying resources, has been approved, diverting resources from other areas of harm that might be more deserving. Those for whom symbols matter are given plenty of room for comment when we observe the bold new front of ASIO on Canberra's Parkes Way, a $\$ 600 \mathrm{~m}$. intelligence megalith.

All of these developments are explicable historically, however much we may contest their rationales and effects. What makes them intelligible?

It is noteworthy that in the late 70s independent legal opinion provided to the Hope Protective Security Review considered that the contemporary threat of terrorism could be dealt with largely within the framework of existing law - and that Hope concluded that the police had adequate powers, in conjunction with ASIO's intelligence function, 'to combat and to prevent attacks on VIPs or terrorism likely to occur here'. ${ }^{25}$ It is tempting therefore to join with the run of critics of the fecund law-making of the last decade and be suspicious of the rationales of the Howard government in sponsoring such an expansion of law's reach. Much has been written about the content and intent of the legislation, but here I want to ask whether what has been called 'hyper-legislation' (Roach's characterisation of the notable aspect of the Australian response (Roach, 2011)) is a symptom of something other than the Howard government's self-interested activism. I suggest instead that such creativity is in large part a signal of the transformed law-making environment in criminal law and policing since the 1970s.

The two decades following the Hilton bombing and the Hope Protective Security Review were remarkable in Australia for the success of a program to reform the criminal law. Australia might continue to lack a national Bill of (Human) Rights, but this did not mean the absence from law and government of a discourse that was constantly informed by human 
rights precepts. Indeed, the combination of an absent bill of rights with a constitutionally protected freedom of speech and a vigorous civil society debate over powers and practices of government and policing appears a potent mix for shaping some distinctive Australian strategies in the governance of security (Irving, 2009; Roach, 2011: 355-6).

Successive inquiries by law reform commissions at Commonwealth and State level opened up criminal law to endless scrutiny. Advocacy of a model criminal law for Australia resulted in the enactment of a Commonwealth Criminal Code and some diffusion of its norms into other jurisdictions. Law reform commissions, human rights commissions, and a plethora of royal commissions subjected criminal justice procedure, including policing and corrections to unprecedented inquiry and criticism. Add to these pressures the weight of another two decades of High Court and State Supreme Court judgments shaping the limits of investigation and prosecution and punishment (expanding and limiting as the case may be). Consider too the complex effects of Australian federalism in criminal law and policing - with powers and responsibilities spread across jurisdictions and forcing uncomfortable articulations and collaborations as needed. Turn to criminal and security intelligence and notice the remarkable emergence of intelligence agencies into the limelight, no doubt seizing new opportunities for relevance in a changing post-Cold War world but also subject to new measures of accountability and democratic oversight. Aggregate all these drivers and we have, I suggest, an important explanation for the scale and nature of the legislative response of government in Australia to the events of 2001-5.

When government looked around for effective law in the wake of 9/11 it discovered nothing that dealt with the prevention of terrorism, however much it had been on the agenda of government for nearly 30 years (Williams, 2011: 1161). When it came to legislate for such prevention it faced a field of criminal law that had altered very significantly in its circumspection and accountability compared to the 1970s. A little noticed but symptomatic demonstration of this effect is evident in a provision of the anti-terrorist laws governing the questioning of suspects. Under this provision, a person arrested for a non-terrorism or terrorism offence may be questioned initially for up to 4 hours, unless they happen to be minor under 18 years or an Aboriginal or Torres Strait Islander person, in which case the initial period of questioning is 2 hours. ${ }^{26}$ Such a discrimination on the base of race may or may not be defensible, but is best understood in the light of the changes in criminal justice policies in Australia after the 1970s. Look at the provisions of anti-terrorist law of the last decade and notice its numbing complexity and specificity, seemingly leaving no stone 
unturned in an effort to ensure that policing and intelligence agencies could do their work within the framework of legal regulations that would withstand judicial scrutiny. The fact that in some cases the ambition was fruitless tells us only that laws of evidence still mean something, and that legislative drafting is always an imperfect science.

In a statement of the contemporary impacts of terrorism in Australia characteristic of much commentary it is said that

The new security context has also had a dramatic impact in Australia; political leaders have embraced 'border security', blurring the once separate domains of defence policy and immigration, and debates about refugee policy are increasingly being framed in terms of national security(McDonald, 2007: 589).

Such observations arguably speak more to the discourse of contemporary politics than to an appreciation of the legacy of Australia history. Defence policy, or at the very least, the Commonwealth's defence power, and immigration have been bedfellows since the establishment of the federation. Their affiliation was the object of vehement High Court judgment in 1923 when Justice Isaacs spelled out the 'the enormous public danger arising from persons arriving from abroad, and the necessity ... of a nation guarding itself against dangers all the more serious because not immediately detectable'. ${ }^{27}$

As we have discussed earlier, immigration and border controls were a highlight of planning and practice in the 1970s generation of counter-terrorism policy and practice. These were not primarily ASIO functions, but administered by the departments of immigration and customs. ASIO provided intelligence that informed the making of immigration watch lists, keeping an eye on people moving in and out of Australia, whether citizens or not, and not excluding the judge after whom this lecture is named (Finnane, 2007: 5-6). As for the unwanted, refugee policy was always thought of in terms of national security, although the dimensions of that trope shifted over time. The domestic security objectives of immigration policy were deeply felt by the key politicians and administrators in successive debates over Jewish refugees in the 1930s, or displaced persons in the 1940s and 1950s or the entry of Vietnamese refugees in the 1970s (Bashford and Strange, 2002; McMaster, 2001; Neumann and Tavan, 2009; Neumann, 2004; Nicholls, 2007). It scarcely needs stressing here that immigration will continue to be a key site of counter-terrorism strategies, however constrained by the countervailing politics of immigration policy and the demands of procedural justice. Just this month we have been reminded of the reality of these intersections 
by the High Court's invalidation of a regulation requiring the Minister to refuse a protection visa to a person against whom ASIO has made an adverse security assessment (Plaintiff M472012 v Director General of Security [2012] HCA 46).

This seems a pertinent point at which to conclude these comments on changes as well as continuities in the governance of terrorism since the 1970s. As I have noted earlier there is a striking symptom of the intelligence community's awesome growth since 2001 in the construction of the new and very expensive ASIO headquarters in Canberra's Parliamentary Triangle. But have we reason to see this development as the expression of a feared consolidation of the security state, so much the target of a domestic politics of security in the 1970s and 1980s? The sheer size of the budget, the great expansion of intelligence and associated staff, and the statutory authorisation of expanded powers of surveillance might suggest so. But against this we also need to put the reining in of ASIO by statute, its incorporation into the world of administrative and parliamentary oversight, and the continuing exercise of judicial opinion in respect of its functions in official decision-making, whether in prosecutions or in immigration determinations. Rather than a pretext of terrorism accounting for ASIO's re-established legitimacy from the 1980s I think we have reason to consider the ways in which ASIO itself has become more accountable by virtue of its being part of, more than controlling, the governance of terrorism. Terrorism remains in the $2010 \mathrm{~s}$ as elusive, if persistently threatening, as in the 1970s, the age of its modern emergence as an object of government. 


\section{References:}

Aarons M (2001) War criminals welcome: Australia, a sanctuary for fugitive war criminals since 1945. Melbourne: Black Inc.

Andrew CM (2009) The defence of the realm: the authorized history of MI5. London: Allen Lane.

Ball D and Horner DM (1998) Breaking the codes: Australia's KGB network 1944-1950. Sydney: Allen \& Unwin.

Bashford A and Strange C (2002) Asylum-seekers and national histories of detention. Australian Journal of Politics and History 48(4): 509-527.

Bevege M (1993) Behind Barbed Wire: Internment in Australia During WorldWar II. St. Lucia, Qld: University of Queensland Press.

Braithwaite J (2005) Pre-empting terrorism. Current Issues in Criminal Justice 17(1): 96-114.

Brawley S (ed) (2009) Doomed to repeat? Terrorism and the Lessons of History. New Academia Publishing, LLC.

Briggs E (2011) The Munich Massacre: a New History. Honours, University of Sydney Department of History. Available at: http://hdl.handle.net/2123/7980.

Bronitt S (2003) Australia's legal response to terrorism: neither novel nor extraordinary? Human Rights The Year in Review (2003): 39-54.

Bronitt S (2008) Balancing Security and Liberty: Critical Perspectives on Terrorism Law Reform. In: Gani M and Mathew P (eds) Fresh Perspectives on the War on Terror. Canberra: ANU E Press. Available at: http://epress.anu.edu.au/war_terror/pdf/ch05.pdf.

Bronitt S and Stellios J (2006) Sedition, security and human rights: "unbalanced" law reform in the "War on Terror." Melbourne University Law Review 30(3): 923-960.

Bull M and Craig M (2006) Problem of Terrorism: Balancing Risk between State and Civil Responsibilities, The. Current Issues in Criminal Justice 18: 202.

Burke A (2008) Fear of Security: Australia's Invasion Anxiety. Port Melbourne, Vic: Cambridge University Press.

Cain F (1994) The Australian Security Intelligence Organization: an unofficial history. Richmond, Vic.: Spectrum Publications.

Cain F (2008) Terrorism \& Intelligence in Australia: A History of ASIO\& National Surveillance. North Melbourne, Vic: Australian Scholarly Publishing.

FAD Paper No 23: Policy and Organisation to Counter International Terrorism - Ministers Responsible: Mr Ellicott (Attorney-General) and Mr Withers (Administrative Services) - presented at 
Pre-published draft: Finnane, Terrorism and government

FAD Committee meeting 27 September 1976 - Decision No 1657(FAD) - File No LC942 (1976). file. Canberra. Available at: http://www.naa.gov.au/cgi-bin/Search?O=I\&Number=8938786.

Findlay M (2005) Some brief observations on the significance of deterrence in Braithwaite's "Preempting terrorism." Current Issues in Criminal Justice 17(1): 120-121.

Finnane M (2007) J V Barry: a Life. Sydney: UNSW Press.

Finnane M (2013) The Munich Olympics massacre and the development of counter-terrorism in Australia. forthcoming.

Gani M and Mathew P (eds) (2008) Fresh Perspectives on the War on Terror. Canberra: ANU E Press. Goldsmith A (2005) Pre-empting terrorism - a comment. Current Issues in Criminal Justice 17(1): 115-119.

Grewcock M (2009) Border crimes: Australia's war on illicit migrants. Sydney, N.S.W.: Institute of Criminology Press.

Hall R (1978) The secret state: Australia's spy industry. Stanmore, N.S.W.: Cassell Australia.

Head M (2009) Calling Out the Troops: The Australian Military and Civil Unrest: The Legal. Annandale, NSW: Federation Press.

Hocking J (1993) Beyond Terrorism: The Development of the Australian Security State. St Leonards, N.S.W: Allen \& Unwin.

Hocking J (1997) Lionel Murphy: a political biography. Cambridge ; Melbourne: Cambridge University Press.

Hocking J (2004) Terror laws: ASIO, counter-terrorism and the threat to democracy. Sydney: UNSW Press.

Horner DM (2002) SAS: phantoms of war: a history of the Australian Special Air Service. St Leonards, N.S.W.: Allen \& Unwin.

Irving H (2009) Australia. In: Thiel M (ed) The "Militant Democracy" Principle in Modern Democracies. Ashgate.

Jones DM (2010a) What's wrong with terrorism studies? Australian Journal of International Affairs 64(4): 478-483.

Jones DM (2010b) Intelligence and national security: The Australian experience. The Oxford Handbook of National Security Intelligence. Oxford: OUP, 823-842. Available at:

http://espace.library.uq.edu.au/view/UQ:230143.

Koschade S (2007) Constructing a Historical Framework of Terrorism in Australia: From the Fenian Brotherhood to 21st Century Islamic Extremism. Journal of Policing, Intelligence and Counter Terrorism 2(1): 54-76. 
Pre-published draft: Finnane, Terrorism and government

Lynch A and Williams G (2006) What price security?: taking stock of Australia's anti-terror laws. Sydney: University of New South Wales Press.

Lynch A, Williams G and MacDonald E (eds) (2007) Law and liberty in the war on terror. Leichhardt, N.S.W.: Federation Press.

Manne R (1987) The Petrov affair: politics and espionage. Sydney: Pergamon.

McCulloch J (2001) Blue army: paramilitary policing in Australia. Carlton South, Vic.: Melbourne University Press.

McCulloch J and Pickering S (2009) Pre-Crime and Counter-Terrorism: Imagining Future Crime in the "War on Terror."British Journal of Criminology 49: 628-645.

McDonald K (2007) Terrorism. In: Galligan B and Roberts W (eds) The Oxford Companion to Australian Politics. Melbourne: Oxford University Press.

McGarrity N, Lynch A and Williams G (eds) (2010) Counter-Terrorism and Beyond: The Culture of Law and Justice after 9/11. T \& F Books UK.

McKnight D (1994) Australia's spies and their secrets. St Leonards, NSW: Allen \& Unwin.

McKnight D (2008a) Partisan Improprieties: Ministerial Control and Australia's Security Agencies, 1962-72. Intelligence and National Security 23(5): 707.

McKnight D (2008b) Rethinking Cold War History. Labour History (95): 185-196.

McMaster D (2001) Asylum Seekers: Australia's Response to Refugees. Melbourne, Vic: Melbourne University Press.

Mickolus EF (1980) Transnational terrorism: a chronology of events, 1868-1979. London: Aldwych Press.

Milte K (1975a) Terrorism and international order. ANZ Journal of Criminology 8(2): 101-111.

Milte K (1975b) Prevention of Terrorism through the Development of Supra-National Criminology. Journal of International Law and Economics 10: 519.

Mullins S (2011) Islamist Terrorism and Australia: An Empirical Examination of the "Home-Grown" Threat. Terrorism and Political Violence 23(2): 254-285.

Neumann K (2004) Refuge Australia: Australia's Humanitarian Record. Sydney: UNSW Press.

Neumann K (2006) In the interest of national security: civilian internment in Australia during World War II. Canberra: National Archives of Australia.

Neumann K and Tavan G (eds) (2009) Does history matter?: making and debating citizenship, immigration and refugee policy in Australia and New Zealand. Canberra: ANU E Press. Available at: http://epress.anu.edu.au/. 
Pre-published draft: Finnane, Terrorism and government

Nicholls G (2007) Deported: a history of forced departures from Australia. Sydney, N.S.W.: UNSW Press.

O'Donnell K (2011) From guns, gates and guards: the development of Australia's federal critical infrasturcture policy, 1978-2010. Master of Criminology and Criminal Justice (Honours), Griffith University.

O'Malley P (2011) Security after Risk: Security Strategies for Governing Extreme Uncertainty. Current Issues in Criminal Justice 23: 5.

O'Neil A (2005) The evolving nature of international terrorism and Australia's response. Issues in Australian Crime and Criminal Justice, 377-391.

O’Neil A (2007) Degrading and managing risk: assessing Australia's counter-terrorist strategy. Australian Journal of Political Science 42(3): 471-487.

Palmer D and Whelan C (2006) Counter-terrorism across the Policing Continuum. Police Practice and Research 7(5): 449-465.

Pickering S (2005) Refugees and State Crime. Annandale, NSW: Federation Press.

Poynting S (2004) Bin Laden in the suburbs: criminalising the Arab other. Sydney: Institute of Criminology.

Rawson D (1968) Political violence in Australia. Dissent (Autumn): 18-39.

Reeve S (2011) One Day in September: The Full Story of the 1972 Munich Olympics Massacre and the Israeli Revenge Operation "Wrath of God."Arcade Publishing.

Roach K (2011) The 9/11 Effect: Comparative Counter-Terrorism. Cambridge University Press.

Saul B (2006) Defining Terrorism in International Law. Oxford ; New York: Oxford University Press.

Saunders K (1992) War on the homefront: state intervention in Queensland 1938-1948. St. Lucia, Qld: University of Queensland Press.

Submission No 3810: Review of policy and organisation in relation to counter terrorism - Related to Decision No 10757(IS) and 10921(IS) (1980). file. Canberra. Available at: http://www.naa.gov.au/cgibin/Search?O=I\&Number=30484239.

Turner I (1969) Sydney's burning. Sydney: Alpha Books.

Waghorne J and Macintyre S (2011) Liberty: a history of civil liberties in Australia. Sydney: UNSW Press.

Wardlaw G (1982) Political Terrorism: Theory, Tactics, and Counter-Measures. Cambridge ; New York: Cambridge University Press.

Wardlaw G (1986) Terrorism and public disorder: the Australian context. In: Chappell D and Wilson PR (eds) The Australian Criminal Justice System: The Mid 1980s. Sydney: Butterworths. 
Weber L and Bowling B (2004) Policing Migration: A Framework for Investigating the Regulation of Global Mobility. Policing and Society 14(3): 195.

Williams G (2011) A decade of Australian anti-terror laws. Melbourne University Law Review 35: 1136-1197.

Zedner L (2005) Securing Liberty in the Face of Terror: Reflections from Criminal Justice. Journal of Law and Society 32(4): 507-533.

Zedner L (2009) Fixing the future? the pre-emptive turn in criminal justice. In: McSherry B, Norrie A and Bronitt $\mathrm{S}$ (eds) Regulating deviance: the redirection of criminalisation and the futures of criminal law. Oxford: Hart.

\footnotetext{
${ }^{1}$ Draft resolutions at the UN General Assembly, 27 Nov 1972, 'International terrorism', National Archives of Australia (NAA) A1838, 912/17 Part 2. For the context of debates at the UN see (Saul, 2006: 71-4; Wardlaw, 1982: 105-8)

2 'Possible condolence motion in the House on terrorism [September 1972]', International
} terrorism, NAA A1838, 912/17 Part 2. The recognition of the large Lebanese community was prescient, although it should be noted that Lebanese migration before 1980 was largely Christian. For the significance of Lebanese heritage among so-called 'home-grown terrorists' in Australia in recent years see (Mullins, 2011: 267)

3 'Terrorism and violence in Australia' (Cabinet file re decision 1406, 10 Oct 1972, including Submission 896) NAA A5882 (A5882/2), CO1528.

${ }^{4}$ International law and law enforcement to combat acts of terrorism against civil aviation [Submission No 202 refers], NAA A5931, CL202.

${ }^{5}$ The [portion of title exempt] Report - Visit to ASIO Headquarters by Attorney-General 16 and 23 March 1973, fol. 11, NAA A12383, A/18/2.

6 'Minutes of conference at Attorney-General's Department on 30 August 1973 to discuss possible terrorist activities by Black September Movement in Australia', Interdepartmental Committee on counter terrorism - Part 1, NAA A6980 (A6980T1), S250111.

${ }^{7}$ Conference at Attorney-General's Department on 5 October 1973 to review action in respect of possible terrorist activities in Australia, Interdepartmental Committee on counter terrorism - Part 1, NAA A6980 (A6980T1), S250111.

${ }^{8}$ Age, 19 Sep 1973, pp 1,5; Age, 20 Sep 1973, p 15; SMH, 26 Sep 1973, p 1. The following account draws on relevant archives files, in particular 'Entry into Australia - Abdul Hamid Abdulla Azzam Al Fatah - Agent', NAA A1838, 1453/4531 Part 1. 
${ }^{9}$ Commonwealth of Australia. Parliament, Hansard, 7 Nov 1973 (qn by Senator Greenwood); 26 Sep 1973 (Murphy). In September 1976 an ASIO advice to the Foreign Affairs and Defence Committee of Cabinet on 'Pro Palestinian Terrorists in Australia' reported 'The Israeli Security Service claimed that AZZAM was the leader of the Black September commando which attached the Israeli Embassy in Bangkok in December 1972 and that he had probably been involved in the despatch of letter bombs around the world": ("FAD Paper No 23," 1976). This of course does not indicate anything about the possibility that Israeli officers had interviewed Azzam in Australia.

${ }^{10}$ In December another security deportation was reported, this time an alleged 'Black September agent': Inside Canberra, Dec 14, 1973, press cutting in NAA A6980 (A6980T1), S250111.

${ }^{11}$ Five Palestinian commandos had stormed the Saudi Arabian Embassy in Paris and taken hostages, demanding the release from Jordan of Abu Daoud, the 'architect' of the Munich hostage taking. The protracted outcome involved negotiations for the terrorists to leave the country with a number of Saudi hostages on a place supplied by the Syrian government: (Mickolus, 1980: 406-7).

${ }^{12}$ Draft minutes of meeting at Attorney-General's Department, Canberra on 18 September 1973 to further consider the 'Draft Plan for Anti-Terrorist Action', (p. 6 of draft plan) Interdepartmental Committee on counter terrorism - Part 1, NAA A6980 (A6980T1), S250111

${ }^{13}$ (Reeve, 2011). This was well known at the time in Australia by virtue of ASIO's wide circulation in early 1973 of a translated copy of the German government's internal review of the Munich disaster: 'The Surprise Attack on the Israeli Olympic Team: documentation by the Federal Government [of Germany] and the Free State of Bavaria', Terrorist attack on Israeli athletes competing at the Olympic Games, Munich 1972, NAA A1209, 1972/6887. ${ }^{14}$ Draft minutes of meeting at Attorney-General's Department, Canberra on 18 September 1973 to further consider the 'Draft Plan for Anti-Terrorist Action', (p. 5 of draft plan) Interdepartmental Committee on counter terrorism - Part 1, NAA A6980 (A6980T1), S250111

15 For the background proposals, and the Operational Plan for 'Special Precautions', see Letter from L S J Harper to the Secretary, Department of Immigration, 23 November 1973, NAA A6980 (A6980T1), S250111. 
${ }^{16}$ See also Guidelines for the Special Interdepartmental Committee on Counter-Terrorism [March 1976], Special Interdepartmental Committee on Counter Terrorism - Part 4, NAA A6980 (A6980T1), S250917.

${ }^{17}$ Minutes of the second regular meeting of the Special Interdepartmental Committee ... held [at] the Attorney-General's Department ... 19 December 1973, Interdepartmental Committee on counter terrorism - Part 1, NAA A6980 (A6980T1), S250111. For the Rome attack see (Mickolus, 1980: 422-3) - the five Rome terrorists were subsequently imprisoned in Egypt but then released to Libya in December 1974 following a further hi-jacking of a BOAC aircraft.

${ }^{18}$ Minutes of a Special Meeting of the Special Interdepartmental Committee on CounterTerrorism held ... 19 March 1974, Interdepartmental Committee on Counter Terrorism 1974 Part 2, NAA A6980 (A6980T1), S250143. The ASIO file on one Aboriginal activist discloses some of the concerns in play over Aboriginal protest, including alarm at Aboriginal protests during Queen's visit; visits to China by Aborigines; and reports from Papua New Guinea of visits of Aboriginal activists from Australia including Foley: 'Foley, Gary - Volume 1', NAA, A6119, 3871.

19 (“Submission No 3810,” 1980).

${ }^{20}$ In 1975 in fact Darwin had been withdrawn from the international airport network and Alice Springs was to be the location for handling any hijacking situations in North Australia: 'Minutes of the Regular Meeting ... 8 January 1975', Interdepartmental Committee on Counter Terrorism, 1975 - Part 3, NAA A6980 (A6980T1), S250788.

${ }^{21}$ See especially Interdepartmental Committee on Counter Terrorism, 1975 - Part 3, NAA A6980 (A6980T1), S250788

${ }^{22}$ Inside Canberra, Dec 14, 1973, press cutting in NAA A6980 (A6980T1), S250111.

${ }^{23}$ Minutes of the Regular Meeting ... 8 January 1975, Interdepartmental Committee on Counter Terrorism, 1975 - Part 3, NAA A6980 (A6980T1), S250788.

${ }^{24}$ FAD Paper No 23: Policy and Organisation to Counter International Terrorism... FAD Committee meeting 27 September 1976 - Decision No 1657(FAD) - File No LC942 (1976) NAA, A12934, FAD23.

${ }^{25}$ See Protective Security Review, 1979, p. 73 (3.73); and Appendix 9, 'Opinion of Sir Victor Windeyer ... on certain questions considering the position of members of the defence force when called out to aid the civil power', p. 446: 'Since all forms of violent wrongdoing that are called terrorism are punishable as crimes under Commonwealth or State law, it seems 
to me questionable whether the importation into Australian law and Defence instructions of the word 'terrorism, as a concept in law, is useful or desirable', NAA A12930, 312 Attachment. See also (Hocking, 2004: 200; Jones, 2010b: 837).

${ }^{26}$ See Crimes Act 1914 paras 23C(4)(a) and 23DB(5)(a), noted, though without comment, in the 2011 Report of the Independent National Security Monitor, p. 39 (http://www.dpmc.gov.au/inslm/index.cfm).

${ }^{27}$ Isaacs J, in R v MacFarlane [1923] HCA 39

(http://www.austlii.edu.au/au/cases/cth/HCA/1923/39.html 